\title{
Salinity Influence on Copper Sulphate and Lead Nitrate Combined Toxicity Against Oreochromis niloticus
}

\author{
${ }^{*}$ F.I. Osuala, K.A. Bawa-Allah and N. Uba \\ Ecotoxicology and Conservation Unit, Department of Zoology, University of Lagos, Lagos, 23401, Nigeria \\ [ ${ }^{*}$ Corresponding Author: E-mail: fhilosu@yahoo.com; 8: +234(0)8056226064]
}

\section{ABSTRACT}

Brackish water ecosystems characterized by fluctuating physicochemical parameters are more susceptible to the toxic effects of heavy metals acting singly or jointly. This study investigated the effect of salinity variations on the joint action toxicity of copper sulphate $\left(\mathrm{CuSO}_{4}\right)$ and lead nitrate $\mathrm{Pb}\left(\mathrm{NO}_{3}\right)_{2}$ against fingerlings of Oreochromis niloticus. Fingerlings were exposed to binary mixtures of $\mathrm{CuSO}_{4}$ and $\mathrm{Pb}\left(\mathrm{NO}_{3}\right)_{2}$ (ratios $1: 1$ and $1: 4)$ at varying salinities $(0 \%, 2 \%, 12 \%$ and $18 \%$ ) in laboratory bioassays. The binary mixtures of the heavy metals were least toxic to the fish at $12 \%$ with $96 \mathrm{~h} \mathrm{LC}_{50}$ values of $115.558 \mathrm{mg} \mathrm{l}^{-1}$ and $198.274 \mathrm{mg} \mathrm{l}^{-1}$ compared to $8.465 \mathrm{mg} \mathrm{l}^{-1}$ and $16.884 \mathrm{mg} \mathrm{l}^{-1}$ for $0 \%, 46.084 \mathrm{mg} \mathrm{l}^{-1}$ and $69.843 \mathrm{mg} \mathrm{l}^{-1}$ for $2 \%$ and $13.196 \mathrm{mg} \mathrm{l}^{-1}$ and $100.567 \mathrm{mg} \mathrm{l}^{-1}$ for $18 \%$ at ratios $1: 1$ and $1: 4$ respectively. Analysis using the Synergistic Ratio Model (SR) showed that both heavy metals were less toxic to the fish species when acting jointly irrespective of ratio than when acting singly at $12 \%$. Therefore, the need to consider the fluctuating salinity and joint interaction of heavy metals in setting ecologically safe limits for the discharge of effluents containing heavy metals into the aquatic ecosystems is important.

Key words: Salinity, Heavy Metals, Toxicity, Oreochromis niloticus

\section{NTRODUCTION}

Heavy metals are toxic elements that occur naturally in rocks and soils. However, anthropogenic activities have resulted in elevated concentrations in the environment especially in aquatic ecosystems. Aquatic pollution by heavy metals is a recurrent environmental problem globally because these metals are nondegradable and persists in the environment long after polluting event have been contained. Several studies (Otitoloju, 2002; Pandey and Madhuri, 2014; Sehar et al., 2014) have investigated the toxic effect of various heavy metals on aquatic organisms. However, the physicochemical property of the aquatic environments in which heavy metal pollution occurs is a major factor that has not been frequently considered in these ecological studies. The brackish water ecosystem is characterized by fluctuating salinity in relation to tide and season. It has been reported that salinity may affect the availability of metal ions due to metal complexation by chlorides, and competition by cations such as $\mathrm{Na}^{+}, \mathrm{Mg}^{2+}$, and $\mathrm{Ca}^{2+}$ (Bianchini and Gilles, 2000; Paquin et al., 2000; Bianchini et al., 2002; Gensemer et al., 2002; Janssen et al., 2003). A few studies have investigated the effect of salinity on metal toxicity in aquatic organisms. Osuala and Bawa-Allah $(2013,2014)$ carried out studies to investigate the effect of salinity on single action toxicity of copper and lead salts respectively against Oreochromis niloticus. They reported that both metals were least toxic to the species at 12 parts per thousand (\%o) compared to the other salinities tested $(0 \%, 2 \%$ and $18 \% 0)$. $\mathrm{Li}$ et al. (2008) demonstrated that the $\mathrm{LC}_{50}$ (median lethal concentration) values of boron $(B)$ in white shrimp Litopenaeus vannamei at 3.0\% were significantly lower than those at $20 \%$ after 48, 72, and 96 hour exposure. Martins et al. (2011) also reported that acute Cu toxicity in the blue crab Callinectes sapidus was higher at 2\%o salinity than at 30\%o salinity. Kwok and Leung (2005) also demonstrated that increasing salinities from $15 \%$ to $45 \%$ significantly reduced the toxicity of $\mathrm{Cu}$ and tributyltin (TBT) to Tigriopus japonicus. However, heavy metals seldom exits in isolation in polluted aquatic ecosystems rather 


\section{Osuala et al: Salinity Influence on Copper Sulphate and Lead Nitrate Combined Toxicity Agains......}

in mixture interacting and influencing individual toxicity, hence there is a need to study the effects of salinity variations in brackish water ecosystems on toxicity of heavy metals mixtures against aquatic organisms. Thus, this study assessed the effect of salinity variations on the toxicity of $\mathrm{CuSO}_{4}$ and $\mathrm{Pb}(\mathrm{NO} 3)_{2}$ mixtures against O. niloticus.

\section{MATERIALS AND METHOD Test Organism}

Oreochromis niloticus fingerlings were used as the test organisms in this study. Fingerlings with average weight of $0.70 \pm 0.04 \mathrm{~g}$, average length of $4.00 \pm 2.00 \mathrm{~cm}$ and aged 2-4weeks were bought from a fish farm in Lagos State, Nigeria. Fishes were transported in a $25 \mathrm{~L}$ container half filled with pond water and opened at the top for aeration, to the Ecotoxicological unit, Department of Zoology laboratory, University of Lagos, Nigeria. The fingerlings were transferred to holding tanks $(50 \mathrm{~cm} \times 30 \mathrm{~cm} \times 35 \mathrm{~cm})$ that was half filled with dechlorinated water and allowed to acclimatize to laboratory conditions (temperature $28.00 \pm 2.00^{\circ} \mathrm{C}$ and relative humidity $79.00 \pm$ $2.00 \%$ ) for 7 days. During the acclimatization period, the fingerlings were fed twice daily with fish feed (coppens) at 3\% body weight.

\section{Test Chemicals}

Copper sulphate salt as $\mathrm{CuSO}_{4} \cdot 5 \mathrm{H}_{2} \mathrm{O}$ and lead nitrate salt as $\mathrm{Pb}\left(\mathrm{NO}_{3}\right)_{2}$ purchased from FISONS laboratory were used as test chemicals in this study.

\section{Preparation of Varying Salinity of Exposure Media}

Seawater was collected from a beach located in Lagos State, Nigeria and used to prepare the test media with varying salinity. Media with $2 \%, 12 \% 0$ and 18\% maximum salinity limit (Osuala and Bawa- allah, 2014) were prepared by mixing predetermined amount of seawater with dechlorinated tap water. The salinity of the prepared media was confirmed using the Lohand electronic refractometer.

\section{Preparation of Test Media with Heavy Metals}

Stock solutions of binary mixtures of $\mathrm{CuSO}_{4}$ and $\mathrm{Pb}\left(\mathrm{NO}_{3}\right)_{2}$ (1:1 and 1:4 w/w) were prepared by taking computed amount of test compounds which were made up to a desired volume with distilled water, to achieve solutions of $1 \mathrm{gL}^{-1}$. For 1:1 mixture, $0.5 \mathrm{~g}$ of $\mathrm{CuSO}_{4}$ and $0.5 \mathrm{~g}$ of $\mathrm{Pb}(\mathrm{NO} 3)_{2}$ was made up to $1 \mathrm{~L}$ to give a stock solution strength of $1 \mathrm{gL}^{-1}$. For $1: 4$ mixture, $0.2 \mathrm{~g}$ of $\mathrm{CuSO}_{4}$ and $0.8 \mathrm{~g}$ of $\mathrm{Pb}(\mathrm{NO} 3)$ was made up to $1 \mathrm{~L}$ to give a stock solution strength of $1 \mathrm{gL}-1$. The solutions were mixed together using a glass rod to ensure proper mixing. To prepare test media for bioassays, the stock solutions were serially diluted using water of varying salinities prepared as described in the previous section. Test media with varying concentrations of metals salts (Table 1) determined after range finding studies were always made up to $2 \mathrm{~L}$, this is because preliminary studies showed that 12 fingerlings survived well in $2 \mathrm{~L}$ media for a period of 7 days without aeration.

Determination of the Relative Acute Toxicity of Binary Mixtures of $\mathrm{CuSO}_{4}$ and $\mathrm{Pb}\left(\mathrm{NO}_{3}\right)_{2}$ against Oreochromis niloticus fingerlings at varying salinity

Circular plastic bowls (volume: $4.0 \mathrm{~L}$, bottom diameter: $15.0 \mathrm{~cm}$ and top diameter: $20.0 \mathrm{~cm}$ ) were used for acute toxicity studies. Twelve (12) active fingerlings were randomly selected and introduced into exposure media (treated and untreated control) at varying salinities as described in the previous section. .

Each treatment was replicated twice to give a total of twenty (24) fingerlings exposed per concentration. Mortality was assessed once every $24 \mathrm{~h}$ for a period of 4 days. Fingerlings were taken to be dead if no body movements including the operculum were observed, even when prodded with a blunt glass rod. 
Table 1: Exposure concentrations of Binary mixtures at varying salinities

Exposure concentrations $\mathrm{mg} \mathrm{L}^{-1}$

\begin{tabular}{|c|c|c|c|c|c|c|c|c|c|}
\hline \multicolumn{5}{|c|}{ Salinity } & \multicolumn{5}{|c|}{$\mathrm{CuSO}_{4}+\mathrm{Pb}\left(\mathrm{NO}_{3}\right)_{2}(1: 1)$} \\
\hline $0 \%$ & 0.0 & 4.5 & 5.5 & 6.5 & 7.5 & 8.5 & 9.5 & 10.5 & 15.5 \\
\hline $2 \%$ & 0.0 & 40 & 46 & 47 & 48 & 50 & & & \\
\hline $12 \%$ & 0.0 & 110 & 130 & 150 & 170 & 190 & & & \\
\hline \multirow[t]{2}{*}{$18 \%$} & 0.0 & 70 & 80 & 90 & 100 & 120 & & & \\
\hline & \multicolumn{9}{|c|}{$\mathrm{CuSO}_{4}+\mathrm{Pb}\left(\mathrm{NO}_{3}\right)_{2}(1: 4)$} \\
\hline $0 \%$ & 0.0 & 5 & 10 & 15 & 20 & 25 & 30 & 35 & \\
\hline $2 \%$ & 0.0 & 50 & 60 & 70 & 90 & 100 & & & \\
\hline $12 \%$ & 0.0 & 100 & 150 & 200 & 250 & 300 & & & \\
\hline $18 \%$ & 0.0 & 100 & 120 & 140 & 180 & 220 & 240 & & \\
\hline
\end{tabular}

Key: $\%=$ Parts per thousand; $\mathrm{CuSO}_{4}=$ Copper sulphate; $\mathrm{Pb}\left(\mathrm{NO}_{3}\right)_{2}=$ Lead nitrate

\section{Statistical Analysis}

The dose-response data of the acute toxicity test of the heavy metals against the test animals was analyzed by probit analysis using SPSS (Statistical Package for Social Sciences) model 16.0. Indices of measuring toxicity $\left(96 \mathrm{hr} \mathrm{LC}_{50}\right)$ and their $95 \%$ confidence limits were employed. The pattern of joint interaction of the binary mixtures were assessed using the Synergistic Ratio (SR) model after Hewlett and Plackett (1969) which assesses the contribution to mixture toxicity of each metal in the mixture.

Synergistic Ratio $(S R)=\frac{\mathrm{LC5} 0 \text { of metal acting singly }}{\mathrm{LC5} 50 \text { of metal mixture }}$ Where: LC: Lethal Concentration

$\mathrm{SR}=1$ describes additive action between metals in mixture

SR $>1$ describes a synergistic action between metals in mixture

$\mathrm{SR}<1$ describes an antagonistic action between metals in mixture

\section{Pattern of Joint Action Interaction}

To assess the pattern of joint interaction of the heavy metals, the toxicity values of the heavy metals acting singly against the same fish species obtained from previous studies (Osuala and Bawa-Allah, 2013; 2014) were compared to joint action toxicity values obtained in this study using SR model.

\section{RESULTS}

\section{Influence of Salinity on the Toxicity of Binary Mixtures of $\mathrm{CuSO}_{4}$ and $\mathrm{Pb}\left(\mathrm{NO}_{3}\right)_{2}$ against Oreochromis niloticus}

\section{Ratio 1:1}

At all the salinities, the toxicity of the binary mixture against the test organism increased with increase in exposure concentrations as shown by the dose-response plot (Figures 1, 2, 3 and 4). The $96 \mathrm{~h} \mathrm{LC} \mathrm{L}_{50}$ values of the binary mixture increased with increase in salinity from $0-12 \%$ o (8.465 mg l-1, $46.084 \mathrm{mg} \mathrm{l}^{-1}$ and $115.558 \mathrm{mg} \mathrm{l}^{-1}$ ) while the value reduced at $18 \%$ (13.196 $\left.\mathrm{mg} \mathrm{l}^{-1}\right)$. This indicated a progressive decrease in toxicity of the mixture against the test organisms with increase in salinity from $0 \%$ to $12 \%$ where the mixture was least toxic against the fingerlings. At $18 \%$, the toxicity effects of the mixture increased compared to that recorded at $2 \%$ and $12 \%$ (Figure 5). 


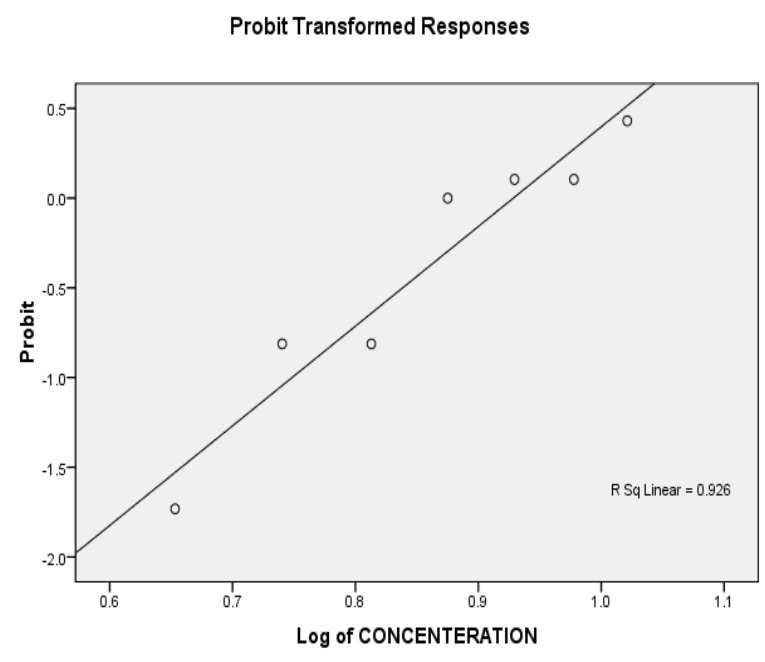

Figure 1: Dose-Response analysis of binary mixture of $\mathrm{CuSO}_{4}$ and $\mathrm{Pb}\left(\mathrm{NO}_{3}\right)_{2}$ against Oreochromis niloticus at 2\%o (Ratio 1:1)

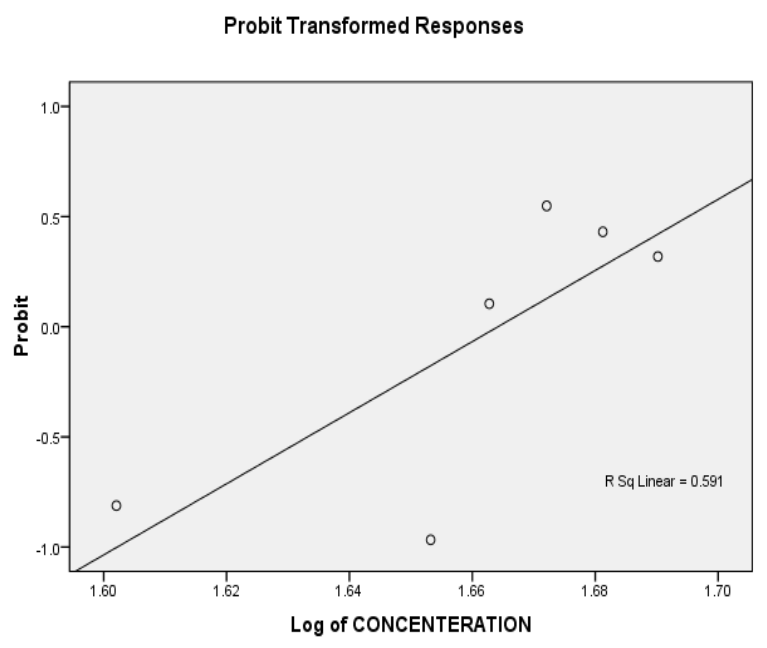

Figure. 2: Dose-Response analysis of binary mixture of $\mathrm{CuSO} 4$ and $\mathrm{Pb}(\mathrm{NO}) 2$ against Oreochromis niloticus at $0 \% 0(1: 1)$

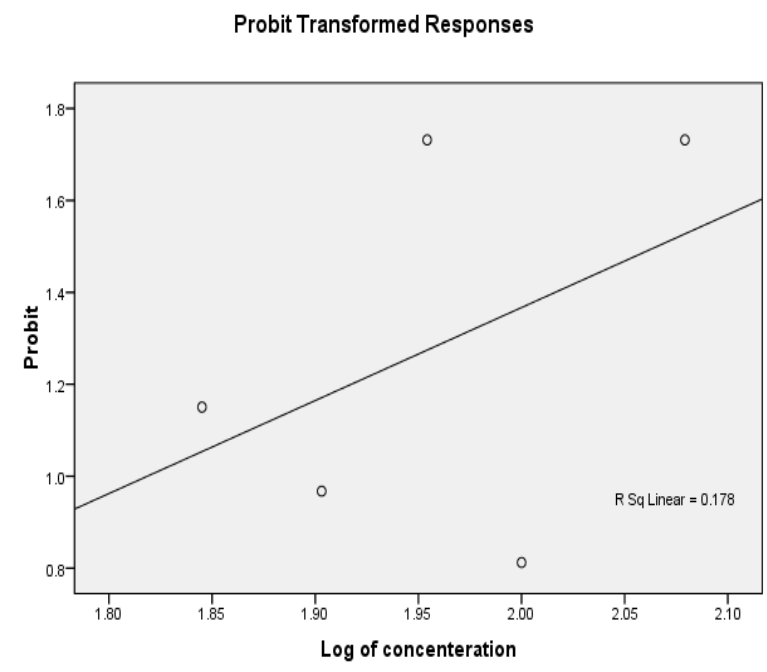

Figure: 3: Dose-Response analysis of binary Mixtureof $\mathrm{CuSO}_{4}$ and $\mathrm{Pb}\left(\mathrm{NO}_{3}\right)_{2}$ against Oreochromis niloticus at 12\%o (Ratio 1:1)

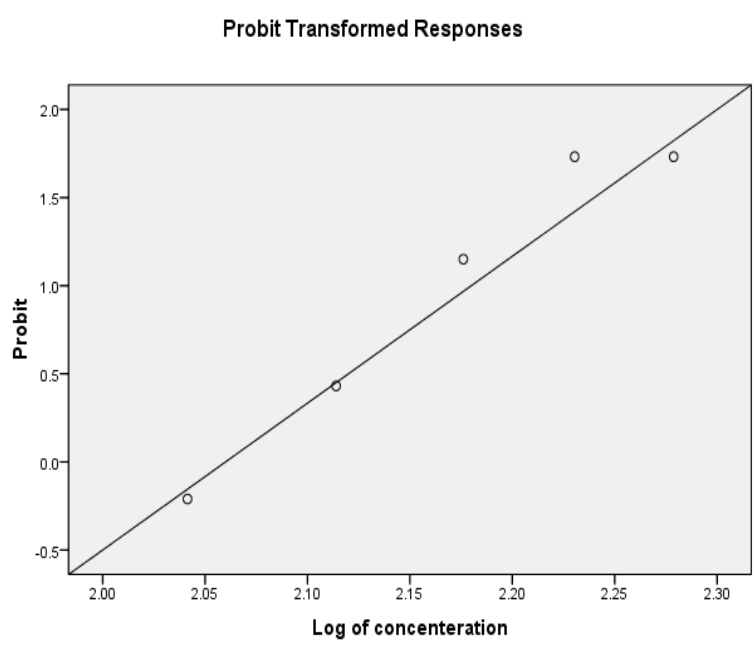

Figure: 4: Dose-Response analysis of binary mixture of $\mathrm{CuSO}_{4}$ and $\mathrm{Pb}\left(\mathrm{NO}_{3}\right)_{2}$ against Oreochromis niloticus at 18\% (Ratio 1:1) 


\section{Nigerian Journal of Basic and Applied Science (June, 2019), 27(1): 01-09}

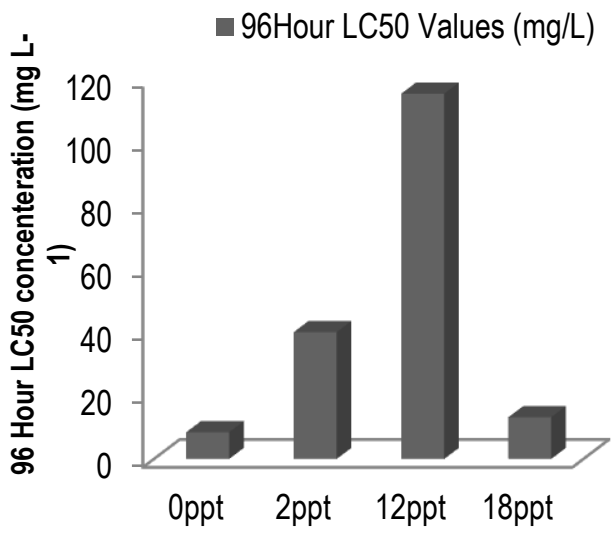

Figure 5: $96 \mathrm{hr} \mathrm{LC}_{50}$ values of binary mixture of $\mathrm{CuSO}_{4}$ and $\mathrm{Pb}\left(\mathrm{NO}_{3}\right)_{2}$ against Oreochromis niloticusat the various salinity levels at ratio 1:1

\section{Ratio 1:4}

Similar to what was observed with binary mixtures at ratio $1: 1$, at all the salinities, the toxicity of the binary mixture at ratio 1:4 against the test organism also increased with increase in exposure concentrations as shown by the doseresponse plot (Figures 6, 7, 8 and 9). The toxicity of the mixture was also lowest at $12 \%$ with a 96 $\mathrm{hr} \mathrm{LC} \mathrm{C}_{50}$ of $198.274 \mathrm{mg} \mathrm{L}^{-1}$ compared to its toxicity at the other salinities $\left(16.884 \mathrm{mg} \mathrm{L}^{-1}, 69.843 \mathrm{mg}\right.$ $\mathrm{L}^{-1}$ and $100.527 \mathrm{mg} \mathrm{L}^{-1}$ at $0 \%, 2 \%$ and $18 \%$ respectively (Figure 10).

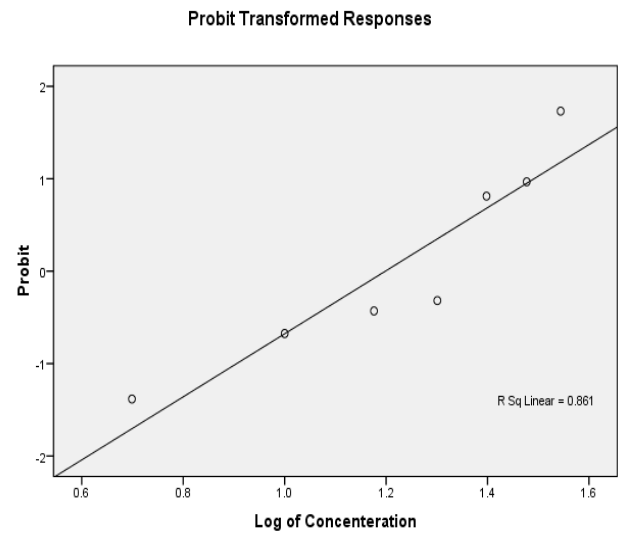

Figure 6: Dose-Response analysis of binary mixture of $\mathrm{CuSO}_{4}$ and $\mathrm{Pb}\left(\mathrm{NO}_{3}\right)_{2}$ against Oreochromis niloticus at 0\%(Ratio 1:4)

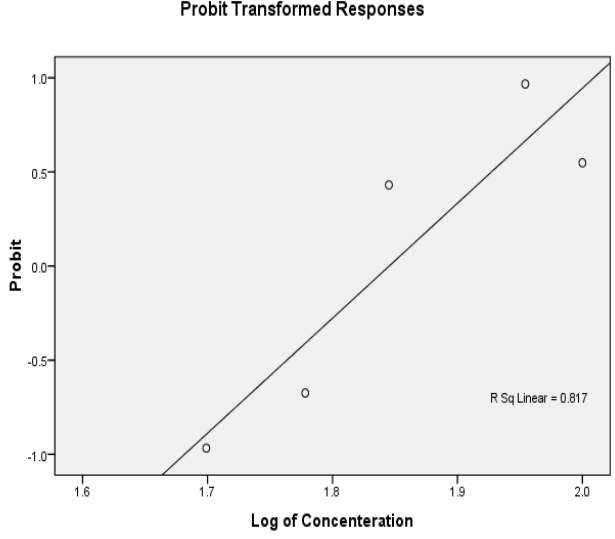

Figure 7: Dose-Response analysis of binary mixture of $\mathrm{CuSO}_{4}$ and $\mathrm{Pb}\left(\mathrm{NO}_{3}\right)_{2}$ against Oreochromis niloticus at 2\%(Ratio 1:4)

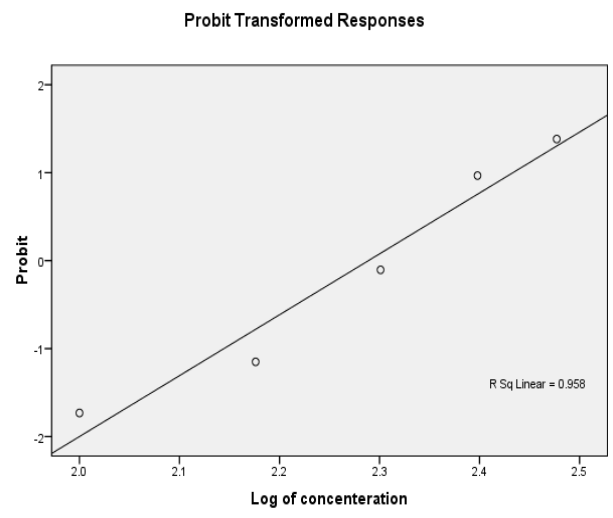

Figure: 8: Dose-Response analysis of binary mixture of $\mathrm{CuSO}_{4}$ and $\mathrm{Pb}\left(\mathrm{NO}_{3}\right)_{2}$ against Oreochromis niloticus at 12\%0 (Ratio 1:4)

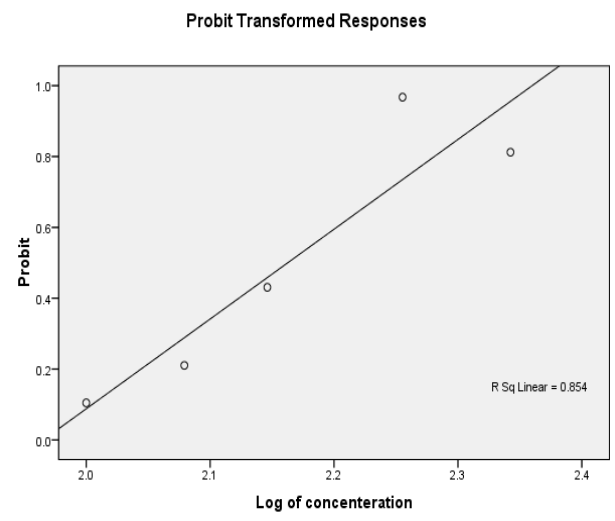

Figure 9: Dose-Response analysis of binary mixture of $\mathrm{CuSO}_{4}$ and $\mathrm{Pb}\left(\mathrm{NO}_{3}\right)_{2}$ against Oreochromis niloticus at 18\%o (Ratio 1:4) 


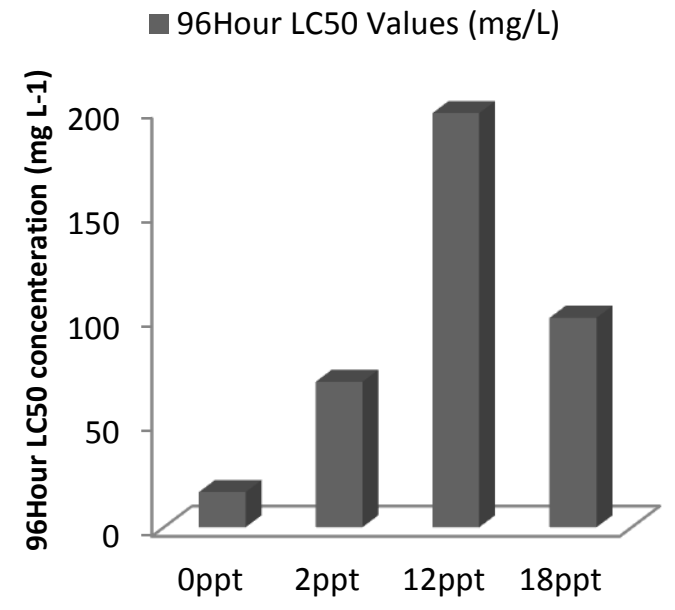

Figure 10: $96 \mathrm{hr} \mathrm{LC}_{50}$ values of binary mixture of CuSO ${ }_{4}$ and $\mathrm{Pb}\left(\mathrm{NO}_{3}\right)_{2}$ against Oreochromis niloticusat the various salinity levels at ratio 1:4

\section{Influence of Binary mixture on toxicity of $\mathrm{CuSO}_{4}$ against Oreochromis niloticus at varying salinities}

For binary mixture at ratio $1: 1, \mathrm{~Pb}\left(\mathrm{NO}_{3}\right)_{2}$ antagonized the toxicity of $\mathrm{CuSO}_{4}$ at $0 \%, 2 \%$ and $12 \%$ with SR values $<1(0.294,0.217$ and 0.240 respectively). However the interaction between
$\mathrm{CuSO}_{4}$ and $\mathrm{Pb}\left(\mathrm{NO}_{3}\right)_{2}$ was synergistic at $18 \%$ with $S R$ value $>1$ (1.272).

For binary mixture at ratio $1: 4, \mathrm{~Pb}\left(\mathrm{NO}_{3}\right)_{2}$ antagonized the toxicity of $\mathrm{CuSO}_{4}$ at all salinities with $S R$ values $<1(0.148,0.143,0.140$ and 0.166 respectively) (Table 2 ).

Influence of Binary Mixture on Toxicity of $\mathrm{Pb}\left(\mathrm{NO}_{3}\right)_{2}$ against Oreochromis niloticus at varying salinities

For binary mixture at ratio 1:1, $\mathrm{CuSO}_{4}$ antagonized the toxicity of $\mathrm{Pb}\left(\mathrm{NO}_{3}\right)_{2}$ at $0 \%$ and $2 \%$ with SR values < 1 (0.381 and 0.135 respectively). At $12 \%$ and $18 \%$ the interaction between $\mathrm{CuSO}_{4}$ and $\mathrm{Pb}\left(\mathrm{NO}_{3}\right)_{2}$ was synergistic with $S R$ values $>1$ (1.126 and 8.578 respectively) (Table 3).

For binary mixture at ratio $1: 4, \mathrm{CuSO}_{4}$ antagonized the toxicity of $\mathrm{Pb}\left(\mathrm{NO}_{3}\right)_{2}$ at $0 \%, 2 \%$ and $12 \%$ with $S R$ values $<1(0.193,0.089$ and 0.656 respectively). At $18 \%$, the interaction between $\mathrm{Pb}\left(\mathrm{NO}_{3}\right)_{2}$ and $\mathrm{CuSO}_{4}$ in the mixture was synergistic (SR value, 1.126) (Table 3).

Table 2: Synergistic ratio values indicating the influence of binary mixture on toxicity of $\mathrm{CuSO}_{4}$ against Oreochromis niloticusat varying salinities

\begin{tabular}{|c|c|c|c|c|c|}
\hline $\begin{array}{l}\text { Binary } \\
\text { mixture } \\
\text { ratio }\end{array}$ & $\begin{array}{l}\text { Salinity Ratio } \\
(\%)\end{array}$ & $\begin{array}{ll}\text { Single } & \text { action } \\
\left.\mathrm{CuSO}_{4}\right) & \mathrm{LC}_{50} \\
\left(\mathrm{mg} \mathrm{l}^{-1}\right) & \end{array}$ & $\begin{array}{l}\text { Mixture } \\
\mathrm{LC}_{50}\left(\mathrm{mg} \mathrm{l}^{-1}\right)\end{array}$ & $\begin{array}{l}\text { Synergistic } \\
\text { Ratio (SR) }\end{array}$ & Remarks \\
\hline \multirow[t]{4}{*}{ 1:1 } & 0 & 2.492 & 8.465 & 0.294 & Antagonistic \\
\hline & 2 & 10.008 & 46.084 & 0.217 & Antagonistic \\
\hline & 12 & 27.785 & 115.558 & 0.240 & Antagonistic \\
\hline & 18 & 16.786 & 13.196 & 1.272 & Synergistic \\
\hline \multirow[t]{4}{*}{$1: 4$} & 0 & 2.492 & 16.884 & 0.148 & Antagonistic \\
\hline & 2 & 10.008 & 69.843 & 0.143 & Antagonistic \\
\hline & 12 & 27.785 & 198.274 & 0.140 & Antagonistic \\
\hline & 18 & 16.786 & 100.527 & 0.166 & Antagonistic \\
\hline
\end{tabular}


Table 3: Synergistic Ratio values Indicating the Influence of Binary Mixture on toxicity of $\mathrm{Pb}\left(\mathrm{NO}_{3}\right)_{2}$ against Oreochromis niloticus at varying salinities

\begin{tabular}{|c|c|c|c|c|c|}
\hline $\begin{array}{l}\text { Binary } \\
\text { mixture } \\
\text { ratio }\end{array}$ & $\begin{array}{l}\text { Salinity Ratio } \\
(\%)\end{array}$ & $\begin{array}{l}\text { Single action } \\
\left.\mathrm{Pb}\left(\mathrm{NO}_{3}\right)_{2}\right) \\
\mathrm{LC}_{50}\left(\mathrm{mg} \mathrm{l}^{-1}\right)\end{array}$ & $\begin{array}{l}\text { Mixture } \\
\text { LC }_{50}\left(\mathrm{mg} \mathrm{l}^{-1}\right)\end{array}$ & $\begin{array}{l}\text { Synergistic } \\
\text { Ratio (SR) }\end{array}$ & Remarks \\
\hline \multirow[t]{4}{*}{$1: 1$} & 0 & 3.255 & 8.465 & 0.381 & Antagonistic \\
\hline & 2 & 6.243 & 46.084 & 0.135 & Antagonistic \\
\hline & 12 & 130.094 & 115.558 & 1.126 & Synergistic \\
\hline & 18 & 113.191 & 13.196 & 8.578 & Synergistic \\
\hline \multirow[t]{4}{*}{$1: 4$} & 0 & 3.255 & 16.884 & 0.193 & Antagonistic \\
\hline & 2 & 6.243 & 69.843 & 0.089 & Antagonistic \\
\hline & 12 & 130.094 & 198.274 & 0.656 & Antagonistic \\
\hline & 18 & 113.191 & 100.527 & 1.126 & Synergistic \\
\hline
\end{tabular}

\section{DISCUSSION}

Results from this study showed that the toxicity of the binary mixtures of $\mathrm{CuSO}_{4}$ and $\mathrm{Pb}\left(\mathrm{NO}_{3}\right)_{2}$ irrespective of mixture ratio increased with increasing concentrations against 0 . niloticus. This was an expected dose-response trend reported extensively in toxicology studies. One major innate characteristic that contributes to the success of 0 . niloticus is the fact that they are euryhaline in nature and can tolerate brackish water. Euryhaline species are hyper-hypo osmotic organisms (and vice versa) during variations in water salt content of their habitat, but variations tending towards the extremities may result in stress or death.

In this study, the joint action acute toxicity studies carried out on $\mathrm{O}$. niloticus using binary mixtures of $\mathrm{CuSO}_{4}$ and $\mathrm{Pb}\left(\mathrm{NO}_{3}\right)_{2}$ at a ratio of $1: 1$ revealed that the heavy metal mixture was most toxic to the fish at freshwater $(0 \%)$ and least toxic at $(12 \%)$. A similar effect was also observed for the heavy metals mixture at ratio 1:4. These findings corroborates previous findings by Osuala and Bawa-Allah (2013, 2014) who assessed the influence of salinity on the toxicity of copper and lead acting singly, at different salinities against Oreochromis niloticus. They reported that the two metal salts were most toxic to the fish at freshwater in separate single action toxicity studies, contrary to expectations that since bred under freshwater conditions, they will show more tolerance to the heavy metals in fresh water. Oyewo (1998) has also previously reported that other similar brackish water adapted bony fishes such as Tilapia guinensis and Nerite senegalensis were known to be most susceptible to heavy metal pollutants including $\mathrm{CuSO}_{4}$ at salinities tending towards the extremities (below $5 \%$ and above 25\%o), but were several folds more tolerant at salinities of up to $15 \%$ which falls within typical brackish water salinity (10$20 \%$ ).

The pattern of interaction between $\mathrm{CuSO}_{4}$ and $\mathrm{Pb}\left(\mathrm{NO}_{3}\right)_{2}$ at the two mixture ratios were further investigated by analyzing data obtained from previous studies by Osuala and Bawa-Allah $(2013,2014)$ and those obtained from this study using the Synergistic Ratio Model.

At the ratio $1: 1$, the interaction between $\mathrm{CuSO}_{4}$ and $\mathrm{Pb}\left(\mathrm{NO}_{3}\right)_{2}$ analyzed based on $96 \mathrm{hr} \mathrm{LC}_{50}$ values of $\mathrm{CuSO}_{4}$ and that of the mixture, was antagonistic at $0 \%, 2 \%$ and $12 \%$. This showed that $\mathrm{Pb}\left(\mathrm{NO}_{3}\right)_{2}$ antagonized the toxicity of $\mathrm{CuSO}_{4}$ against the test organisms at these salinities. At $18 \%$, the interaction between $\mathrm{CuSO}_{4}$ and $\mathrm{Pb}\left(\mathrm{NO}_{3}\right)_{2}$ was synergistic, indicating that $\mathrm{Pb}\left(\mathrm{NO}_{3}\right)_{2}$ enhanced the toxic effects of $\mathrm{CuSO}_{4}$ 


\section{Osuala et al: Salinity Influence on Copper Sulphate and Lead Nitrate Combined Toxicity Agains......}

against the species. At ratio $1: 4$, the interaction between $\mathrm{CuSO}_{4}$ and $\mathrm{Pb}\left(\mathrm{NO}_{3}\right)_{2}$ based on $96 \mathrm{hr}$ $\mathrm{LC}_{50}$ values of $\mathrm{CuSO}_{4}$ and that of the mixture, were found to be antagonistic at all the salinity levels $(0 \%, 2 \%, 12 \%$ and $18 \%$ ), indicating that $\mathrm{Pb}\left(\mathrm{NO}_{3}\right)_{2}$ inhibited the toxicity of $\mathrm{CuSO}_{4}$ at this mixture ratio at all salinities.

The pattern of interaction between $\mathrm{CuSO}_{4}$ and $\mathrm{Pb}\left(\mathrm{NO}_{3}\right)_{2}$ analyzed based on $96 \mathrm{hr} \mathrm{LC}_{50}$ values of $\mathrm{Pb}\left(\mathrm{NO}_{3}\right)_{2}$ and that of the mixture showed an antagonistic reaction between $\mathrm{CuSO}_{4}$ and $\mathrm{Pb}\left(\mathrm{NO}_{3}\right)_{2}$ at $0 \%$ and $2 \%$. There was an increase in the $96 \mathrm{hr} \mathrm{LC}_{50}$ value of the mixture as compared to $96 \mathrm{hr} \mathrm{LC}_{50}$ value of $\mathrm{Pb}\left(\mathrm{NO}_{3}\right)_{2}$ when acting singly. Similar result was obtained when the pattern of interaction was analyzed based on 96hr $\mathrm{LC}_{50}$ values of $\mathrm{CuSO}_{4}$ and that of the mixture. This indicated that both heavy metal salts were more toxic to the fish species when acting singly than when acting jointly in a mixture of 1:1. At ratio 1:4 the pattern of interaction between $\mathrm{CuSO}_{4}$ and $\mathrm{Pb}\left(\mathrm{NO}_{3}\right)_{2}$ analyzed based on $96 \mathrm{hr} \mathrm{LC}_{50}$ values of $\mathrm{Pb}\left(\mathrm{NO}_{3}\right)_{2}$ and that of the mixture, was antagonistic at $0 \%, 2 \%$ and $12 \%$ similar to results obtained at ratio 1:1. At 18\%, the interaction between the metals was synergistic. This indicates that acting singly, $\mathrm{Pb}\left(\mathrm{NO}_{3}\right)_{2}$ is less toxic to the species than when it is in a mixture with $\mathrm{CuSO}_{4}$ at $18 \%$. $\mathrm{CuSO}_{4}$ enhanced the toxicity of $\mathrm{Pb}\left(\mathrm{NO}_{3}\right)_{2}$ at this salinity level.

According to Bryan and Gibbs (1983), the mechanism responsible for antagonistic interaction between constituent metal components in a mixture can be attributed to the competition for uptake/binding sites in the biological interface between the various types of metals. Salinity probably increased or reduced the uptake of either $\mathrm{CuSO}_{4}$ or $\mathrm{Pb}\left(\mathrm{NO}_{3}\right)_{2}$ as the case may have been. Observation of synergism could be theoretically based on the fact that the heavy metals formed complexes, which may have greater penetrability with respect to the tissues of the exposed animals than the individual metals acting alone and in such instances, the resultant toxicity of the mixture could be higher than the toxicity of the individual metals acting alone (Ezeonyejiakuet al., 2014).

\section{CONCLUSION}

This study has shown that brackish water species are least susceptible to heavy metal pollution at optimum brackish water salinity conditions (10\% - 15\%o). This implies that separate ecological safe limits for the discharge of industrial effluents should be developed for brackish water ecosystems which would incorporate the fluctuating salinity characteristic of the ecosystem, rather than adopting safe limits developed for the marine ecosystem as is done in many developing countries including Nigeria. It is recommended that the pattern of joint action toxicity of metals should be taken into consideration in setting ecological safe limits for the discharge of effluents containing metals in order to have a complete protection of aquatic ecosystems.

\section{REFERENCES}

Bianchini, A. and Gilles, R. (2000). Is the digestive tract an important access route for mercury in the Chinese crab Ericheir sinensis (Crustacea, Decapoda)? Bulletin of Environmental Contamination and Toxicology, 64:412-417.

Bianchini, A., Grosell, M., Gregory, S.M. and Wood, C.M. (2002). Acute silver toxicity in aquatic animals is a function of sodium uptake rate. Environmental Science and Technology, 36: 1763-1766.

Bryan, G.W. and Gibbs, P.E. (1983). Heavy metals in the Fal estuary, Cornwall: $A$ study of long term contamination by mining waste and its effects on estuarine organisms. Occasional Publications. Marine Biological Association of the United Kingdom, 2: 112.

Ezeonyejiaku, C.D., Obiakor, M.O. and Okonkwo C.D. (2014). Predictive modelling of heavy interactions in environmental setting: laboratory stimulatory approach. Environmental and Ecology Research, 2(6): 248-252. 


\section{Nigerian Journal of Basic and Applied Science (June, 2019), 27(1): 01-09}

Gensemer, R.W., Naddy, R.B., Stubblefield, W.A., Hockett, J.R., Santore, R. and Paquin, P. (2002). Evaluating the role of ion composition on the toxicity of copper to Ceriodaphnia dubia in very hard waters. Comparative Biochemistry and Physiolology, 133:87-97.

Hewlett, P. S. and Plackett, R. L. (1969). A unified theory for quantal responses to mixtures of drugs: Non-interactive action. Biometrics, 15: 591-610.

Janssen, C.R., Heijerick, D.G., De Schamphelaere, K.A. and Allen, H.E. (2003). Environmental risk assessment of metals: tools for incorporating bioavailability. Environment International, 28:793-800.

Kwok, K.W.H. and Leung, K.M.Y. (2005). Toxicity of antifouling biocides to the intertidal harpacticoid copepod Tigriopus japonicus (Crustacea, Copepoda): effects of temperature and salinity. Marine Pollution Bulletin, 51: 830-837.

Li, E., Xiong, Z., Chen, L., Zeng, C. and Li, K. (2008). Acute toxicity of boron to juvenile white shrimp, Litopenaeus vannamei, at two salinities. Aquaculture, 278:175178.

Martins, C.D., Barcarolli, I.F., De Menezes, E.J., Giacomin, M.M., Wood, C.M. and Bianchini, A. (2011). Acute toxicity, accumulation and tissue distribution of copper in the blue crab Callinectes sapidus acclimated to different salinities: in vivo and in vitro studies. Aquatic Toxicology, 101: 88-99.

Osuala, F.I. and Bawa-Allah, K.A. (2013). effects of salinity variations on acute toxicity of copper sulphate against Oreochromis niloticus fingerlings in laboratory bioassays. Journal of Environmental Science, Toxicology and Food Technology, 6(6):22-27.

Osuala, F.I. and Bawa-Allah, K.A. (2014). Mortality assessment of Oreochromis niloticus fingerlings in varying salinity and influence of Salinity changes on acute toxicity of lead. African Journal of Environmental Science and Technology, 8(11): 664-669.

Otitoloju, A.A. (2002). Evaluation of the joint action toxicity of binary mixtures of heavy metals against the mangrove periwinkle Tympanotonus fuscatus var radula (L). Ecotoxicology and Environmental Safety, 53(3): 404-415.

Oyewo, E.O. (1998). Industrial sources and distribution of heavy metal in lagos lagoon and their biological effects on estuarine animals. ph.dthesis,university of lagos. pp230-274.

Paquin, P.R., Santore, R.C., Wu, K.B., Kavvadas, C.D. and Di Toro, D.M. (2000). The biotic ligand model: a model of the acute toxicity of metals to aquatic life. Environmental Science Policy, 3:175182.

Pandey, G. and Madhuri, S. (2014). Heavy Metals causing toxicity in animals and fishes. Research Journal of Animal, Veterinary and Fishery Science, 2(2): 1723.

Sehar, A., Shafaqat, A., Uzma, S. A., Mujahid, F., Saima A., Fakhir, H. and Rehan, A. (2014). Effects of different heavy metal pollution on fish. Research Journal of Chemistry and Environmental Science, 2:74-79. 